\title{
Exploring farmers' perception on climate-induced events and adaptation practices to protect crop production and livestock farming in Haor area of northeastern Bangladesh
}

\section{Tasneem Chowdhury Fahim ( $\sim$ fahimc01@gmail.com )}

Institute of Disaster Management and Vulnerability Studies, University of Dhaka https://orcid.org/0000-0003-4949-0701

\section{Bivuti Bhushan Sikder}

Institute of Disaster Management and Vulnerability Studies, University of Dhaka

\section{Research Article}

Keywords: Climate change, perception, climate change adaptation, crop production, livestock, Haor, resilience ORCID ID. 0000-0003-4949-0701

Posted Date: June 18th, 2021

DOI: https://doi.org/10.21203/rs.3.rs-623790/v1

License: (c) (1) This work is licensed under a Creative Commons Attribution 4.0 International License. Read Full License

Version of Record: A version of this preprint was published at Theoretical and Applied Climatology on January 31st, 2022. See the published version at https://doi.org/10.1007/s00704-021-03907-3. 


\section{Abstract}

Bangladesh is confronting terrible impacts of climate change on agriculture across the country, especially in the low-lying area like- Haor, coastal region, and islands. This behavioral study $(\mathrm{N}=320)$ examines the perception and knowledge of farmers on climate-induced events and experiences, and explores the adaptation practices they adopt to protect crop production and livestock farming from the impact of climate change in the Northeastern Haorarea of the country. Using triangulation method, it is detected that farmers of the study area have erroneous idea on climate change and the causes of frequent climate extremes. Study results show that respondents' perception and experiences on climate-induced event are verified positively with the historical trend and time-series analysis of climate indicators as well as with the findings of researchers using PRA tools and techniques. This study explores the traditional and systematic adaptation approaches of farmers which are practiced in individual or community level. The rationale of each of the approach from respondents' side is also analyzed in the study. It is statistically tested using chi-square that some of the scientific and systematic adaptation options for crop production is predominantly influenced by the educational qualifications of the respondents. The study reveals that lack of proper information prevents subsistence farmers to find the most effective adaptation pathways.

\section{Introduction}

Climate change has been emerged as one of the most burning issues of our time triggering perilous effects on natural and human systems across the world (Intergovernmental Panel on Climate Change [IPCC], 2014, p. 3). Increasing piles of empirical evidence identify anthropogenic emissions is mostly responsible for global climate crises. According to the fifth IPCC report, anthropogenic GHG emissions as well as other forcings are responsible together for increasing more than half of the average surface temperature worldwide from 1951 to 2010 (Easterling, Kunkel, Wehner, \& Sun, 2016, p. 17; Bindoff et al., 2013, pp. 869-870; Knutson, Kossin, Mears, Perlwitz, \& Wehner, 2017, pp. 114-115). Due to its topography, Bangladesh is regarded as one of the most climate-vulnerable deltas of the world holding 7th position in the "Long-Term Climate Risk Index (CRI)", calculated using 4 indicators for the twenty-year period (1999-2018). Climate change poses vital threats to food security, livelihood, agriculture, ecosystem services etc. in Bangladesh (Eckstein, Kunzel, Schafer, \& Winges, 2019, p. 9; Coirolo, Commins, Haque, \& Pierce, 2013, p. 75; Alam, 2018, pp. 195-197; Becker et al., 2020, p. 1867; Anik \& Khan, 2012, pp. 879-880). "Climate Crisis" is responsible for decreasing food production around the world, particularly in the developing countries (International Fund for Agricultural Development, IFAD, 2010, p. 15; The Guardian, 2019). Researchers recognized risk of climate extremes, changes in mean precipitation and temperature, increasing concentration of atmospheric $\mathrm{CO}_{2}$, climate change induced pest attack etc. are affecting global crop production (Wreford, Moran, \& Adger, 2010, pp. 18-19; IPCC, 2014, pp. 6-7; Deryng, Conway, Ramankutty, Price, \& Warren, 2014, p. 2). Contrarily, some studies report that increased temperature driven carbon fertilization will moderately increase production (Chen, Zhang, \& Tao, 2018, p. 559; Deryng, Conway, Ramankutty, Price, \& Warren, 2014, p. 2). Map of global decrease in crop production 
by Cline (2007) recognizes 30\% decrease in production even with carbon fertilization in Indian subcontinent due to changing climate.

There isn't much scientific evidence to show the interaction between climate change and livestock farming (Thornton, van de Steeg, Notenbaert, \& Herrero, 2009, p. 114; Escarcha, Lassa, \& Zander, 2018, pp. 1-2). However, contemporary studies suggest that climate change is expected to arrest livestock farming by affecting animal production as well as quantity and quality of food and forage; by worsening health, growth, and reproduction; by generating disease and pest attack; and by affecting livestock through climate extremes (Mader \& Gaughan, 2011, p. 42; Rotter \& Van de Gejin, 1999, p. 652; Food and Agriculture Organization of the United Nations, FAO, 2016, p. 5).

Bangladesh is principally an agricultural land. According to Bangladesh Bureau of Statistics, BBS (2020), agriculture sector adds $14.23 \%$ to the GDP of Bangladesh and more than $40.60 \%$ people labor for this sector (p. 3). Changing climate and climate extremes (e. g. flood, drought, salinity, cyclone, tidal surge, heavy rainfall, high temperature, excessive fog etc.) are affecting yielding of crops and livestock farming across Bangladesh where coastal region, islands and Haor area are exceedingly affected (Monwar et al., 2014, p. 126; Hossain, Nayeem, \& Majumder, 2017, pp. 42-43). Haor is a low lying large tectonic depression covering 8584.6 square $\mathrm{km}$, situated in the northeastern 7 districts of Bangladesh. Three hundred and seventy three Haors of Bangladesh receive surface runoff water from several rivers descending from the hills of India, where water remains either stagnant or in flash flooding condition during the months of June to November and Haors remain dry next of the year (Alam, Quayum, \& Islam, 2010, p. 88; Center for Environmental and Geographic Information Services [CEGIS], 2012, pp. 1-2; Kamruzzaman \& Shaw, 2018, pp. 40-41). Most of the Haors of Bangladesh are situated in Sunamganj, Netrokona, Kishoreganj, Sylhet, Habiganj, Moulvibazar, and Brahmanbaria Districts. Haor economy is principally based on agricultural activities as most of the inhabitants are farmers or fishermen. In the dry season they cultivate Rabi crops (crops cultivated from mid-November to mid-March) in their own land or work as sharecroppers and landless agricultural labors; whereas in the wet season they go for fishing in the Haors and rivers. 2017 flash flood severely affected Haor area of Bangladesh, caused suffering of 1 million people, damage of crops worth USD 450 million and loss of thousands of livestock they used to rear (Kamal et al., 2018, p. 482; CEGIS, 2012, p. 2). Though, according to Huq (2017), attributing climate change to 2017 flash flood in Haorarea is very difficult, some researchers accuse climate change responsible for that flood (Ferdushi, Ismail, \& Kamil, 2019, pp. 1-2; Mahtab, Ohara, \& Rasmy, 2018, pp. 67).

Proper adaptation strategies can mitigate the impacts of climate change on crop production and livestock farming and help people coping with the extreme climatic conditions (Nelson, Adger, \& Brown, 2007, p. 396; Alam, Alam, \& Mushtaq, 2017, p. 52). Farmers of either technologically advanced or developing countries, are using modern as well as traditional techniques to adapt to the quickly changed global climate. Integration of modern technology and traditional or indigenous knowledge is bringing out the best pathway of adaptation (Ferdushi, Ismail, \& Kamil, 2019, p. 2). According to IPCC (2014), climate change adaptation refers to "the process of adjustment to actual or expected climate and its effects. In 
human systems, adaptation seeks to moderate or avoid harm or exploit beneficial opportunities. In some natural systems, human intervention may facilitate adjustment to expected climate and its effects" (p. 5). Effectiveness of adaptation strategies towards crop production and livestock rearing is widely dependent on farmer's perception and knowledge on climate and climate induced events (Mertz, Mbow, Reenberg, \& Diouf, 2009, pp. 804-805). According to Maddison (2007), adaptation process includes two componentsperception on climate change and adaptation approaches. Whereas adaptation process itself includes "people's perception" as a main component, inevitably this element is significant while choosing the best adaptation approach by the native farmers. Therefore, this study has been undertaken with the aims to i) find out farmer's perception on climate induced events and ii) explore the adaptation strategies adopted by local people to strengthen their resilience (p.2).

\section{Materials And Methodology}

\subsection{Profile of the Study Area}

Netrokona, a northeastern district of Bangladesh, surrounded by Garo Hills of Meghalaya of India on the north, Kishoreganj District on the south, on the east by Sunamganj District, and Mymensingh District on the west. Netrokona District is situated in between $24^{\circ} 34^{\prime}$ and $25^{\circ} 12^{\prime}$ north latitudes and in between $90^{\circ} 00^{\prime}$ and $91^{\circ} 07^{\prime}$ east longitudes. The district has an area of 2794.28 square kilometers $(1078.87$ square miles). The annual average temperature of Netrokona is highest $33.3^{\circ} \mathrm{C}$ and lowest $12^{\circ} \mathrm{C}$; while the annual average rainfall is $2174 \mathrm{~mm}$ (BBS, 2013, p. 3; Banglapedia, 2015a).

This study was conducted in Haor area of Netrokona District. Sixty-five Haors are found in the district covering 6 upazilas (sub-districts) [Netrokona District has 10 upazilas] with approximately 78,266 hectares of land. After examining the area and quantity of Haor, settlement, exposure, intensity, and sensitivity of people and assets to different climate extremes- 3 upazilas were purposively selected for the study: Khaliajuri, Madan, and Mohanganj.

\subsection{Methods of Data Collection}

This study is a behavioral research. Mixed method was applied to conduct the study which facilitated to find out elaborated and in-depth information to better understand the problems. Quantitative data was collected by a survey using a structured questionnaire. After collecting quantitative data, it was crosschecked with qualitative (Key Informant Interview- KII and Focus Group DiscussionFGD) and secondary data which ensures proper data triangulation of the study. Primary and secondary both types of data were collected. To prepare the climatic hazard index, Participatory Rural Appraisal (PRA) tools and techniques- FGD, transect walk, mapping, and hazard calendar were used.

\subsection{Sampling Frame, Technique, Sample Selection, and Distribution}

2.3.1 Sampling Frame: Farmers of all socioeconomic status, land owners, agricultural and nonagricultural laborers, housewives (who also work for processing crops and/or rear livestock), and people 
of diverse occupations who are associated with agricultural activities as secondary occupations were surveyed for quantitative part of the study. For qualitative part, local important persons, representatives of local government, government officers, NGO activists, academics, and experts were included.

2.3.2 Sampling Technique: The approach to the study involves two stages: i) Field survey and ii) Qualitative interview with the local people, key informants, and experts. Probability sampling was employed in the quantitative part of the study. Stratified random sampling has been applied to represent the population groups which are involved in crop cultivation and livestock rearing in the selected study area.

2.3.3 Sample Selection and Distribution: 320 respondents were surveyed while conducting the study. The number of respondents has been assigned considering the establishment of the area and number of population and degree of exposure and sensitivity of the people as well (Table 1). Besides, $22 \mathrm{KII}$ and 6 FGD participants participated in qualitative part of the study (Table 2).

Table 1 Sample Size Distribution for Quantitative Study

\begin{tabular}{|llll|}
\hline Upazila (Sub-district) & Union & Village & Sample Size \\
\hline Khaliajuri & Chakua & Bolli & 51 \\
\cline { 2 - 4 } & Mendipur & Nurpur Boali & 49 \\
\hline Madan & & Gobindasree & 59 \\
\cline { 3 - 4 } & Gobindasree & Padamsree & 41 \\
\hline Mohanganj & Suair & Bhatia & 31 \\
\cline { 2 - 4 } & Gaglajur & Barantar & 52 \\
\cline { 2 - 4 } & Tethulia & Bara Paikura & 37 \\
\hline Total & & & 320 \\
\hline
\end{tabular}

Table 2 Quantity of Qualitative Study Participants and FGDs

\subsection{Data Analysis}

IBM SPSS Statistical Software (version 25) and Microsoft Excel were used to analyze collected data. Coding of questions helped quantify data where about $95 \%$ of the quantitative variables were categorical. Correlation, chi square, and likelihood ratio- these tests have identified if there is any association between the variables and the measured the strength of association. Significance value $p<0.05$ (Confidence level 95\%) was considered to verify the statistical significance. Using trendline in Microsoft Excel helped to find 


\begin{tabular}{|llll|}
\hline Type of participants & $\begin{array}{l}\text { Number of } \\
\text { Klls }\end{array}$ & $\begin{array}{l}\text { Name of Upazila (Sub- } \\
\text { district) }\end{array}$ & $\begin{array}{l}\text { Number of } \\
\text { FGDs }\end{array}$ \\
\hline Local important persons & 5 & Khaliajuri & 2 \\
\hline $\begin{array}{l}\text { Representatives of local } \\
\text { government }\end{array}$ & 7 & Madan & 2 \\
\hline NGO activists & 2 & Mohanganj & 2 \\
\hline Government officers & 5 & & 6 \\
\hline Experts/Academicians & 3 & Total & \\
\hline Total & 22 & & \\
\hline
\end{tabular}

out the trend of climatic indicators. The map of the study area was prepared using ArcMap 10.8.

\section{Results}

\subsection{Profile of the Respondents of Quantitative Part of the Study}

Total 320 people were surveyed for quantitative part during the field study. All the respondents are either directly or indirectly associated with agricultural activities. Most of the respondents are in the age group $31-40(33.4 \%)$ where age of $0.9 \%$ respondents are below 20 . Only $3.1 \%$ people could pass higher secondary degree, $33.8 \%$ have primary education, and $41.9 \%$ have no schooling. So, most of the agrarian people of Haor area are formally uneducated, though most of them fall in the age group 41-50 (42.54\%) who were born in between 1970s and 1980s when the literacy rate of Bangladesh was between $16.4 \%$ (1974) to 29.23\% (1981) (Banglapedia, 2015b; The Global Economy, 2020). Among the respondents, $55.3 \%$ respondents have family members between 4 and 6 . Data show that $98.8 \%$ respondents do farming during dry period, $41.56 \%$ are fishermen, and $84.38 \%$ rear livestock. Among the respondents, people of other occupations are daily agricultural laborers (19.69\%), daily non-agricultural laborers (14.69\%), rickshaw/van pullers (12.5\%), businessmen (14.7\%), teachers $(2.81 \%)$, housewives $(10.9 \%)$, and students $(0.9 \%)$ etc. Average monthly income of most of the households is within BDT 10001-14000 [USD 118-165] (33.8\%).

\subsection{Major Climatic Hazards affecting Crops and Livestock in the Study Area (Respondents' View)}

According to the respondents, specifically flash flood is the frequently happening (85.6\%) climatic hazard in the study area. It is occurred here from the last of March to July. Sometimes flash flood washes away Boro rice as well as other Rabicrops, and creates economic and social disruption in this region. People identified hailstorm (61.6\%), excessive fog (53.8\%), storm/nor'wester (48.1\%), drought (44.4\%), and 
lightning (38.8\%) as major climatic hazards which affect crop production and livestock farming. They also took cold wave (37.8\%) and heat wave (32.8\%) as two of the major hazards (Fig. 2).

\subsection{People's Perception on Climate Induced Events}

3.3.1 Understanding about Climate Change. $48.1 \%$ people don't have idea about climate change at all. Other people interpreted climate change as a form of different hazards and perturbations. $37.2 \%$ reported that they think climate change as frequent flood, which is the characteristic of the study area. While $27.8 \%$ perceive climate change as extreme heat and $24.7 \%$ find irregularity of seasons as an instance of climate change. Others perceive climate change as frequent storm (20.3\%), excessive cold (18.8\%), irregular weather (13.4\%), heavy precipitation (6.6\%), and less precipitation (2.8\%). From FGDs, it is revealed that most of the people know the term "Climate Change" but meaning of the term is unknown to them.

\subsubsection{Community Perception and Experience of Climate Change:}


Table 3

Community Perception and Experience of Climate Change

\begin{tabular}{|c|c|c|c|c|c|}
\hline \multirow[t]{2}{*}{ Parameters } & \multirow[t]{2}{*}{$\begin{array}{l}\text { Respondents' } \\
\text { Response }\end{array}$} & $\begin{array}{l}\text { Khaliajuri } \\
\text { (\%) }\end{array}$ & $\begin{array}{l}\text { Madan } \\
\text { (\%) }\end{array}$ & $\begin{array}{l}\text { Mohanganj } \\
\text { (\%) }\end{array}$ & $\begin{array}{l}\text { Total } \\
\text { (\%) }\end{array}$ \\
\hline & & $N=100$ & $\begin{array}{l}N= \\
100\end{array}$ & $N=120$ & $\begin{array}{l}N= \\
320\end{array}$ \\
\hline \multirow{4}{*}{$\begin{array}{l}\text { Change in temperature (last } 10 \\
\text { years) }\end{array}$} & Increased & 96 & 95 & 95.83 & 95.63 \\
\hline & Decreased & 1 & 2 & 2.5 & 1.88 \\
\hline & No change & 0 & 1 & 0.83 & 0.63 \\
\hline & Don't know & 3 & 2 & 0.83 & 1.88 \\
\hline \multirow{4}{*}{$\begin{array}{l}\text { Change in the rainfall pattern during } \\
\text { past } 10 \text { years }\end{array}$} & Increased & 34 & 29 & 25.83 & 29.38 \\
\hline & Decreased & 50 & 57 & 60.83 & 56.25 \\
\hline & No change & 9 & 10 & 6.67 & 8.44 \\
\hline & Don't know & 7 & 4 & 6.67 & 5.94 \\
\hline \multirow[t]{4}{*}{ Length of summer season } & Increased & 78 & 75 & 74.17 & 75.63 \\
\hline & Decreased & 10 & 6 & 13.33 & 10 \\
\hline & No change & 7 & 6 & 6.67 & 6.56 \\
\hline & Don’t know & 5 & 13 & 5.83 & 7.81 \\
\hline \multirow[t]{4}{*}{ Length of winter season } & Increased & 46 & 32 & 50.83 & 43.44 \\
\hline & Decreased & 40 & 45 & 35.83 & 40 \\
\hline & No change & 12 & 9 & 2.5 & 7.5 \\
\hline & Don't know & 2 & 14 & 10.83 & 9.06 \\
\hline \multirow[t]{4}{*}{ Length of rainy season } & Increased & 46 & 27 & 32.5 & 35 \\
\hline & Decreased & 36 & 48 & 53.33 & 46.25 \\
\hline & No change & 13 & 17 & 6.67 & 11.88 \\
\hline & Don’t know & 5 & 8 & 7.5 & 6.88 \\
\hline \multirow[t]{3}{*}{$\begin{array}{l}\text { Change in the inundation time in the } \\
\text { Haor area during the past } 10 \text { years }\end{array}$} & $\begin{array}{l}\text { Late } \\
\text { inundation }\end{array}$ & 43 & 46 & 60 & 50.31 \\
\hline & $\begin{array}{l}\text { Early } \\
\text { inundation }\end{array}$ & 41 & 35 & 28.33 & 34.38 \\
\hline & No change & 13 & 15 & 10 & 12.5 \\
\hline
\end{tabular}




\begin{tabular}{|c|c|c|c|c|c|}
\hline \multirow[t]{3}{*}{ Parameters } & $\begin{array}{l}\text { Respondents' } \\
\text { Response }\end{array}$ & $\begin{array}{l}\text { Khaliajuri } \\
\text { (\%) }\end{array}$ & $\begin{array}{l}\text { Madan } \\
(\%)\end{array}$ & $\begin{array}{l}\text { Mohanganj } \\
(\%)\end{array}$ & $\begin{array}{l}\text { Total } \\
\text { (\%) }\end{array}$ \\
\hline & & $N=100$ & $\begin{array}{l}N= \\
100\end{array}$ & $N=120$ & $\begin{array}{l}N= \\
320\end{array}$ \\
\hline & Don't know & 3 & 4 & 1.67 & 2.81 \\
\hline \multirow{3}{*}{$\begin{array}{l}\text { Climatic hazards occur more } \\
\text { frequently than before }\end{array}$} & Yes & 92 & 95 & 96.67 & 94.69 \\
\hline & No & 3 & 3 & 1.67 & 2.5 \\
\hline & Don't know & 5 & 2 & 1.67 & 2.81 \\
\hline \multirow[t]{3}{*}{ Types of flood, occurring in the area* } & Flash flood & 83 & 92 & 90.83 & 88.75 \\
\hline & Rain fed flood & 76 & 84 & 70 & 76.25 \\
\hline & River flood & 9 & 6 & 12.5 & 9.38 \\
\hline
\end{tabular}

\subsubsection{Perception on the Reasons of Frequent Hazards/Disasters:}

The study finds that $45.9 \%$ people still think "Act of God" is the reason of frequent hazards/disasters and $19.7 \%$ identified "Act of Nature" in this regard. Only $18 \%$ respondents recognized "Climate Change" as responsible for frequent hazards and disasters. Other identified reasons are embankment breaching $(17.8 \%)$, onrush of upstream water $(12.8 \%)$, low geographical location $(11.6 \%)$, poverty $(9.1 \%)$, unplanned development (8.4\%), and population growth (4.7\%). 11.6\% respondents don't know any reason of frequent hazards/disasters.

\subsection{Climatic Trends and Hazard Index to Validate People's Perception}

To validate people's perception on climatic parameters (temperature and precipitation), Time-series (TS) Data of Climatic Research Unit (CRU) of University of East Anglia was collected which provides $0.5 \times 0.5$ degree high resolution gridded data (Version 4.03) for 1901-2018 (Harris \& Jones, 2020). Figures 5 and 6 show TS data on annual average temperature $\left({ }^{\circ} \mathrm{C}\right)$ and annual precipitation $(\mathrm{mm})$ for 38 years $(1981-$ 2018). It is evident from the trendlines (Figs. 5 and 6) that during the 1981-2018 average temperature of Netrokona District increased where annual precipitation decreased which supports respondents' perception and experience. Figure 5 illustrates that after 2000 average annual temperature has been increased remarkably.

The parameters of the climatic hazards used to rank are: frequency, area impact, and magnitude of hazards, where each of the parameter got value from 1 to 5 indicating their levels of strength. Ranking of the hazards were based on total score obtained from the formula- Total Score= (Frequency + Area Impact) 
$\times$ Magnitude. Flash flood ranked top and hailstorm followed it; whereas cold wave scored the lowest. The hazard ranking partially endorses identified major hazards affecting crop production and livestock farming by the respondents.

Table 4

Climatic Hazard Index of the Study Area

\begin{tabular}{|c|c|c|c|c|c|}
\hline Hazard & $\begin{array}{l}\text { Frequency } \\
\text { (Value 1-5)* }\end{array}$ & $\begin{array}{l}\text { Area Impact } \\
\text { (Value 1-5)* }\end{array}$ & $\begin{array}{l}\text { Magnitude } \\
\text { (Value 1-5)* }\end{array}$ & Total Score ${ }^{a}$ & Rank \\
\hline Flash flood & 4 & 4 & 4 & 32 & 1 \\
\hline Drought & 2 & 3 & 4 & 20 & 4 \\
\hline River bank erosion & 2 & 3 & 3 & 15 & $7 * \star$ \\
\hline Storm/Nor'wester & 4 & 3 & 3 & 21 & 3 \\
\hline Lightning & 4 & 2 & 3 & 18 & $5^{\star \star}$ \\
\hline Heat wave & 3 & 2 & 3 & 15 & $6 * \star$ \\
\hline Cold wave & 3 & 2 & 2 & 10 & 8 \\
\hline Excessive fog & 4 & 2 & 3 & 18 & $5^{\star \star}$ \\
\hline Hailstorm & 5 & 3 & 3 & 24 & 2 \\
\hline \multicolumn{6}{|c|}{$\mathrm{a}=$ Total score $=($ Frequency + Area Impact $) \times$ Magnitude } \\
\hline \multicolumn{6}{|c|}{ * Value $1-5$ indicates the levels of strength where 1 is the lowest and 5 is the highest value } \\
\hline \multicolumn{6}{|c|}{$\begin{array}{l}* \star \text { If scores are level, priority selection is based on the values of } 1 . \text { Magnitude, } 2 \text {. Frequency, 3. Area } \\
\text { Impact }\end{array}$} \\
\hline
\end{tabular}

Researchers agreed that vulnerable communities can be resilient by following local level adaptation strategies (Alam, Alam, \& Mushtaq, 2017, p. 54; Hiwasaki, Luna, Syamsidik, \& Shaw, 2014, p. 17) which can mitigate the impacts of climatic hazards and minimize the losses. The adaptation strategies of the study area are categorized in 3 categories below: 
Table 5

Adaptation Strategies followed by the Local People of the Study Area

\begin{tabular}{|c|c|c|c|c|c|}
\hline \multirow[t]{3}{*}{ Category } & \multirow[t]{3}{*}{ Adaptation Options } & \multicolumn{4}{|c|}{ Percentage } \\
\hline & & $\begin{array}{l}\text { Khaliajuri } \\
(\%)\end{array}$ & $\begin{array}{l}\text { Madan } \\
(\%)\end{array}$ & $\begin{array}{l}\text { Mohanganj } \\
(\%)\end{array}$ & $\begin{array}{l}\text { Total } \\
(\%)\end{array}$ \\
\hline & & $N=100$ & $\begin{array}{l}N= \\
100\end{array}$ & $N=120$ & $\begin{array}{l}N= \\
320\end{array}$ \\
\hline \multirow{13}{*}{$\begin{array}{l}\text { Crop } \\
\text { Production }\end{array}$} & Crop rotation & 17 & 15 & 24.17 & 19.06 \\
\hline & $\begin{array}{l}\text { Changing crop varieties (e.g. fast- } \\
\text { growing crop) }\end{array}$ & 30 & 46 & 37.5 & 37.81 \\
\hline & $\begin{array}{l}\text { Using stressor tolerant crops } \\
\text { species }\end{array}$ & 30 & 31 & 34.17 & 31.88 \\
\hline & $\begin{array}{l}\text { Early harvesting of immature Boro } \\
\text { rice }\end{array}$ & 40 & 27 & 40.83 & 36.25 \\
\hline & Changing crop planting dates & 55 & 64 & 61.67 & 60.31 \\
\hline & Using mechanical irrigation system & 30 & 28 & 18.33 & 25 \\
\hline & Rainwater harvesting for irrigation & 13 & 17 & 12.5 & 14.06 \\
\hline & Using pesticide to the crops & 53 & 49 & 55.83 & 52.81 \\
\hline & Preservation of crop seeds & 19 & 23 & 11.67 & 17.5 \\
\hline & Homestead gardening & 33 & 41 & 40 & 38.13 \\
\hline & $\begin{array}{l}\text { Planting Hijoland Koroch trees to } \\
\text { protect crop lands from intense } \\
\text { current of flood }\end{array}$ & 15 & 20 & 23.33 & 19.69 \\
\hline & $\begin{array}{l}\text { Using Kanda (High fallow land in } \\
\text { Haor) for cultivating crops other } \\
\text { than rice }\end{array}$ & 41 & 52 & 42.5 & 45 \\
\hline & $\begin{array}{l}\text { Planting palm trees to prevent } \\
\text { lightning }\end{array}$ & 27 & 33 & 43.33 & 35 \\
\hline \multirow{5}{*}{$\begin{array}{l}\text { Livestock and } \\
\text { Poultry } \\
\text { Farming }\end{array}$} & $\begin{array}{l}\text { Preservation of feeds for livestock } \\
\text { for the period of feed scarcity }\end{array}$ & 30 & 33 & 35.83 & 33.13 \\
\hline & $\begin{array}{l}\text { Purchasing feeds for the animals } \\
\text { during the time of feed scarcity }\end{array}$ & 33 & 32 & 27.5 & 30.63 \\
\hline & $\begin{array}{l}\text { Putting cotton/jute made cover on } \\
\text { the animals in winter }\end{array}$ & 36 & 41 & 32.5 & 36.25 \\
\hline & $\begin{array}{l}\text { Constructing permanent } \\
\text { sheds/shelters for animals }\end{array}$ & 20 & 19 & 20 & 19.69 \\
\hline & $\begin{array}{l}\text { Take animals to the veterinary } \\
\text { physician }\end{array}$ & 46 & 37 & 40.83 & 41.25 \\
\hline
\end{tabular}




\begin{tabular}{|c|c|c|c|c|c|}
\hline & Grass cultivation for livestock & 16 & 18 & 15.83 & 16.56 \\
\hline & Duck rearing & 45 & 47 & 36.67 & 42.5 \\
\hline & $\begin{array}{l}\text { Integrated livestock and poultry } \\
\text { farming }\end{array}$ & 12 & 9 & 14.17 & 11.88 \\
\hline \multirow{7}{*}{$\begin{array}{l}\text { Non- } \\
\text { agricultural } \\
\text { Activities }\end{array}$} & Migration of farming family & 44 & 46 & 54.17 & 48.44 \\
\hline & Using different means of livelihood & 54 & 50 & 49.17 & 50.94 \\
\hline & \multicolumn{5}{|l|}{ Cottage industries } \\
\hline & $\begin{array}{l}\text { Taking loans (with high interest) } \\
\text { from lenders }\end{array}$ & 47 & 39 & 42.5 & 42.81 \\
\hline & Selling/Mortgaging property & 48 & 37 & 52.5 & 46.25 \\
\hline & $\begin{array}{l}\text { Selling of livestock in the emergency } \\
\text { period }\end{array}$ & 48 & 37 & 36.67 & 40.31 \\
\hline & $\begin{array}{l}\text { Seeking early warning of different } \\
\text { disasters from the authority }\end{array}$ & 7 & 5 & 5 & 5.63 \\
\hline
\end{tabular}

\subsection{Rationale (Respondents' View) for Available Adaptation Options in the Study Area}


Table 6

Rationale (Respondents' View) for Available Adaptation Options

\section{SI. Adaptation Options Addressed Climatic Risks \\ Rationale (Respondent's View)}

1 Crop rotation Flash flood, drought

As cultivating only Boro rice creates financial risk, people are leaving their traditional practice to grow only rice during dry season in the Haor area. Hence, some people are cultivating wheat, spices, maize, pulses, potato, vegetable etc., which is ensuring sustainable livelihood practice.

$2 \quad$ Changing crop Flash flood

Some people change crop varieties so that they can varieties (e.g. fastgrowing crop) harvest the crops earlier. This adaptation approach saves their crops from the impacts of flash flood (e. g. lifetime of most common rice variety of Haor area BRRI-29 is 160 days. Contrastingly, lifetime is 140 days for BRRI-28. Though BRRI-29 variety provides more crops, some people are cultivating BRRI-28 for early harvesting).

3 Using stressor tolerant crops species
Flash flood, excessive fog, drought, nor'wester, thunderstorm, heat wave/extreme temperature

Flash flood
Local farmers consult with the local officers of Agricultural Extension Department and plant stressor tolerant crop species which can withstand different climatic stressors; e.g. BRRI-28 Rice, BARI Mustard-14, BARI Onion-1 etc.
$4 \quad$ Early harvesting of immature Boro rice
Sometimes people harvest crops earlier when there is any probability of occurring early flash flood. Almost half amount of the rice is not ripe that time, but this strategy can save up to $60 \%$ of rice. The unripe rice is used as fodder.
Usually farmers plant seedlings of Boro rice in MidPoush (Beginning of January). But as an adaptation strategy, to protect the rice from early flash flood, they occasionally plant seedlings in the beginning of Poush (Mid-December).
During dry season, if crop fields are affected by drought or lack of water for irrigation, people use mechanical irrigation system (e.g. shallow pump) to water the crops and moisturize soil.

Practice of rainwater harvesting to irrigate croplands is in small range in the Haor area. This strategy is used as Community Based Planned Adaptation (CBPA), executed by NGOs

Due to climate change induced warming, insect pests are increasing in the Haor area which is destroying crops. To control pest attacks, people are using pesticides increasingly. 


\section{Sl. Adaptation Options Addressed Rationale (Respondent's View) \\ Climatic Risks}

9 Preservation of crop seeds

Extreme rainfall, flood (monsoon)
Preservation of crop seeds for the next cultivation time ensures availability of good seeds even though there is any climatic hazard occurring. Based on indigenous knowledge, people are practicing this as Individual Level Adaptation (ILA).

10 Homestead Flood (flash and gardening monsoon)
Available land in the homestead are used for gardening which is a sustainable livelihood option for the Haor people as croplands are submerged under water at most of the time of a year. Homestead gardening also ensures proper nutrition of the family members.
As Hijol (Barringtonia acutangula) and Koroch (Pongamia pinnata) trees can live in the submerged or inundated area and can withstand the intense current of flood, some NGOs and government organizations are serving to plant these trees as part of Community Based Planned Adaptation (CBPA) strategy.

Flash flood

12 Using Kanda Haor) for cultivating crops other than rice

13 Planting palm trees Lightning
Kanda means high fallow land which isn't inundated by flood. Traditionally these lands remain fallow all the year round. But now some people are using these lands for planting vegetables, pulses, spices, fruits etc.

Government of Bangladesh (GoB) has taken initiative to plant palm trees across the country to reduce fatalities due to lightning. In the study area this adaptation strategy is being executed by the government organizations.

\section{Preservation of feeds for livestock for the period of feed scarcity}

15 Purchasing feeds for the animals during the time of feed scarcity

16 Putting cotton/jute made cover on the animals in winter

17 Constructing permanent sheds/shelters for animals

\section{Flood (flash and monsoon), extreme rainfall}

Flash flood, drought, nor'wester/storm

Cold wave

Flood (monsoon), heavy rainfall, extreme temperature, heat wave, hailstorm, nor'wester/storm, lightning
People store grass, hay, corns in their houses to feed their animals in rainy season. This adaptation strategy helps their livestock to be survived during any climatic disaster.

Due to heavy rainfall, flood, and storm, sometimes animal fodders are damaged. At that time subsistence farmers have no other option except purchasing fodders.

To keep livestock safe from the effect of cold wave, local people use cotton and/or jute made cover in the winter season.

Previously, it was seen that livestock are kept in the open places during day or night which posed the risks of being affected by climatic hazards. To cope with the situation, people are constructing permanent sheds/shelters at their houses for animals. 


\section{Sl. Adaptation Options Addressed Climatic Risks \\ Rationale (Respondent's View)}

18 Take animals to the veterinary

physician
Climate change induced pestattack and diseases
Traditionally people of remote area are reluctant to bring their sick cattle to the veterinary physician. At present, the situation has been changed. People consult veterinary physician if their domestic animals are affected by climate induced pest-attack and diseases/ other diseases.

Climate change impacts are reducing pasture lands in the Haorarea which is exaggerating scarcity of feeds for the livestock. To meet the demand, farmers are cultivating grass for feeding their animals.
19 Grass cultivation for livestock
Climate change induced fodder scarcity (flash flood, monsoon flood, heavy rainfall, drought etc.)

20 Migration of farming family
Climatic hazards caused livelihood activities disruption

People of the study area migrate to urban and suburban areas for seeking new income generating activities. Usually, this type of migration is seasonal which is happened when crops are damaged by flash floods, or in the rainy season. Seasonal migrants come back to their villages in crop cultivation time.

As most of the lands are submerged under water in wet season, traditionally local people have been practicing duck rearing as an adaptation option.

Flood (flash and monsoon)

21 Duck rearing $\begin{aligned} & \text { Flood (flash and } \\ & \text { monsoon) }\end{aligned}$

22 Integrated livestock and poultry farming

Climate change induced livelihood activity disruption

Climatic hazards induced livelihood activities disruption

With the help of Government of Bangladesh and NGOs, people are rearing goat, sheep, duck, and hen combinedly as these can cope with the climatic condition of Haor area. This livelihood initiative is increasing income of the subsistence farmers.

23 Using different means of livelihood

disruption

24 Cottage industries

Climatic hazards caused livelihood activities disruption

25 Taking loans (with high interest) from lenders

26
Selling/Mortgaging property
Climatic hazards caused livelihood activities disruption

Climatic hazards caused livelihood activities disruption
As an adaptation option, diversified means of livelihood decrease the risk of financial crisis triggered by climate change. From the study we found that most of the respondents have more than one income sources.

Cottage industry is an adaptive livelihood option for women of the Haorarea. Women, associated with cottage industry have a sustainable income as there is institutional arrangement of marketing the products with the help of different NGOs.

In Haor area, lenders provide loan with high interest to the farmers. Usually small farmers take loan during crisis period, which in fact leads them towards another trouble.

Farmers sell or mortgage their properties when there is lack of livelihood opportunities due to any stressor, and they are in need of cash to survive. 


\section{Sl. Adaptation Options Addressed Rationale (Respondent's View) Climatic Risks}

27 Selling of livestock in the emergency period

\section{Seeking early} warning of different disasters from the authority
Climatic hazards caused livelihood activities disruption

Flash flood, monsoon flood, heavy rainfall etc.
Some people have no other option except selling their livestock while they are in financial crisis. Selling livestock helps them to cope up with the terrible condition in the emergency.

Seeking early warning of different disasters is very rare in the Haor area of Bangladesh. One of the reasons is- traditionally people can forecast disasters by observing sky and water of Haor and river. Nevertheless, nowadays people are seeking early warning from Union Councils and Department of Agricultural Extension (DAE) so that they can take precautions to save their crops.

\subsection{Educational Level Influencing some Systematic Adaptation Options}

Some scientific and systematic adaptation options for crop production is largely influenced by the educational qualifications of the respondents. From the quantitative and qualitative analysis, it has been observed in the Haor area of Netrokona District that farmers having no formal education or lower level of education are more reluctant to follow scientific recommendations of adaptation techniques like- crop rotation, changing crop varieties, using stressor tolerant crop species etc. than the educated ones.

Traditional farmers hardly can accept scientific and new strategies.

It is statistically tested through that switching crop varieties (crop rotation), changing crop varieties, and using stressor tolerant crops species have strong association with the level of education in the study area (Table 7).

Table 7

Educational Qualifications have Strong Relationships with some Scientific Adaptation Options

\begin{tabular}{|c|c|c|c|c|c|}
\hline Variable & Adaptation Option & $\begin{array}{l}\text { Statistical } \\
\text { Test }\end{array}$ & Value & df & Significance ${ }^{*}$ \\
\hline \multirow[t]{3}{*}{$\begin{array}{l}\text { Educational } \\
\text { Qualifications }\end{array}$} & $\begin{array}{l}\text { Switching crop varieties } \\
\text { (Crop rotation) }\end{array}$ & $x^{2}$ & $25.041^{a}$ & 7 & .001 \\
\hline & Changing crop varieties & $x^{2}$ & $15.525^{\mathrm{a}}$ & 7 & .030 \\
\hline & $\begin{array}{l}\text { Using stressor tolerant crops } \\
\text { species }\end{array}$ & $x^{2}$ & $16.567^{a}$ & 7 & .020 \\
\hline
\end{tabular}

\subsection{Causes of not Taking Adaptation Measures}

107 farmers responded on the reasons of not taking proper adaptation measures. $63.4 \%$ respondents identified lack of information as the main reason of not taking any adaptation measure. $33.9 \%$ people 
said that lack of money prevents them to take adaptation measures, although money is not so required for adaptation. $30.6 \%$ respondents don't know the reason; $26.2 \%$ are not aware of climate change which can motivate them to take adaptation measure. On the other hand, $9.8 \%$ respondents aren't interested in this matter.

\section{Concluding Remarks}

Climate change-induced reduced crop production and livestock is affecting food security, livelihood, health, and exaggerating the extent of poverty and social insecurity in the country (Chen, Zhang, \& Tao, 2018, p. 543; Barnett \& Adger, 2007, pp. 639-640). This study examined the perception and knowledge of farmers on climate-induced events and experiences, and explored the adaptation practices they adopt to protect crop production and livestock farming from the impact of climate change in the Haors of northeastern area in Bangladsh. Study result shows that respondents' perception and experiences on climate-induced events are verified empirically, but most of the respondents have vague idea on climate change. The study extensively explored the adaptation approaches of the farmers which include some good practices like- crop rotation, changing crop varieties, using stressors tolerant crop species, integrated livestock and poultry farming, using different means of livelihood etc. It is observed that farmers of Haor area are reluctant to follow crop diversification strategy; rather they stick to traditional Boro rice cultivation. Department of Agricultural Extension can work here exclusively to motivate people on crop diversification. More research and innovation are also needed in this arena. Local livestock department can commence awareness activities to aware livestock rearers. As naturally agriculture is very vulnerable here due to geographic location, non-farm activities should be enhanced as adaptation options. Government and non-government bodies can work closely to promote more non-farm adaptation activities. As the global temperature trend is going upward, risk of climate extremes is also being accelerated. Therefore, to adapt to changed climate, policy level interventions are required for livelihood diversification and integrating indigenous and scientific knowledge which will efficiently increase resilience of native people of the Haorarea.

\section{Declarations}

\section{Funding}

The research is part of master's thesis of Mr. Tasneem Chowdhury Fahim under the supervision of Mr. Bivuti Bhushan Sikder, Assistant Professor of Institute of Disaster Management and Vulnerability Studies, University of Dhaka. The research is totally self-funded.

\section{Conflict of Interest/Competing Interest}

Mr. Tasneem Chowdhury Fahim and Mr. Bivuti Bhushan Sikder declare that they have no conflict of interest regarding this original research article. The authors have completed the research with their own funding. They have no affiliations with or involvement in any organization with any financial interest. 
Availability of Data and Material

Data and materials are available. It can be shared upon editor's/reviewers' suggestions.

\section{Code Availability}

No code availability

\section{Authors' Contribution}

Mr. Tasneem Chowdhury Fahim executed the research in field level with his own funding. He collected data with his team, analyzed data and wrote the research paper under the supervision of Mr. Bivuti Bhushan Sikder. Mr. Bivuti Bhushan Sikder also reviewed the article when needed.

\section{Ethical Approval}

This article is original and the manuscript hasn't been submitted to more than one journal for simultaneous consideration. The submitted work hasn't been published elsewhere before. The data is original, honest and hasn't been fabricated.

No people or animals were harmed during executing the research in the field level.

\section{Consent to Participate}

In this research, the respondents and participants are human and prior consent was ensured before conducting the study.

\section{Consent for Publication}

The respondents and participants of this research have given their consent to publish their opinion in the research paper. All the authors are agreed to publish this research paper.

\section{References}

Alam, E. (2018). Climate impacts and adaptation strategies of the Bangladeshi coastal communities. Retrieved September 27, 2020 from https://thescipub.com/pdf/10.3844/ajessp.2018.195.202.pdf

Alam, G. M. M., Alam, K., \& Mushtaq, S. (2017). Climate change perceptions and local adaptation strategies of hazard-prone rural households in Bangladesh. Climate Risk Management, 17, 5263. https://doi.org/10.1016/j.crm.2017.06.006

Alam, M. S., Quayum, M. A., \& Islam, M. A. (2010). Crop production in the Haorareas of Bangladesh: Insights from farm level survey. The Agriculturists, 8(2), 88-97. https://doi.org/10.3329/agric.v8i2.7582 
Anik, S. I., \& Khan, M. A. S. A. (2012). Climate change adaptation through local knowledge in the north eastern region of Bangladesh. Mitigation and Adaptation Strategies for Global Change, 17(8), 879896. https://doi.org/10.1007/s11027-011-9350-6

Bangladesh Bureau of Statistics. (2013). District statistics 2011: Netrokona. Dhaka, Bangladesh: Bangladesh Bureau of Statistics.

Bangladesh Bureau of Statistics. (2020). Yearbook of agricultural statistics-2019: $31^{\text {st }}$ series. Dhaka, Bangladesh: Bangladesh Bureau of Statistics.

Banglapedia. (2015a). Netrokona district. Retrieved September 30, 2020 from http://en.banglapedia.org/index.php?title=Netrokona_District

Banglapedia. (2015b). Literacy. Retrieved October 13, 2020 from http://en.banglapedia.org/index.php? title=Literacy\#: :text=

Barnett, J., \& Agder, W. N. (2007). Climate change, human security and violent conflict. Political Geography, 26(6), 639-655. https://doi.org/10.1016/j.polgeo.2007.03.003

Becker, M., Papa, F., Karpytchev, M., Delebecque, C., Krien, Y., Khan, J. U., . . \& Calmant, S. (2020). Water level changes, subsidence, and sea level rise in the Ganges-Brahmaputra-Meghna delta. Proceedings of the National Academy of Sciences, 117(4), 1867-1876. https://doi.org/10.1073/pnas.1912921117

Bindoff, N. L., Stott, P. A., AchutaRao, K. M., Allen, M. R., Gillett, N., Gutzler, D., . . Zhang, X. (2013). Detection and attribution of climate change: From global to regional. In T. F. Stocker, D. Qin, G. K. Plattner, M. M. B. Tignor, S. K. Allen, J. Boschung, . . . P. M. Midgley (Eds.), Climate change 2013: The physical science basis. Contribution of working group I to the fifth assessment report of the Intergovernmental Panel on Climate Change. Retrieved November 23, 2020 from https://www.ipcc.ch/report/ar5/wg1/

Center for Environmental and Geographic Information Services. (2012a). Master plan of Haor area: Volume II: Main report. Bangladesh: Department of Bangladesh Haor and Wetlands Development. Retrieved 28 Septemeber, 2020 from https://dbhwd.portal.gov.bd/sites/default/files/files/dbhwd.portal.gov.bd/publications/29 8d5166_988c_4589_96cb_36e143deba4f/Haor\%20Master\%20Plan\%20Volume\%202.p df

Chen, Y., Zhang, Z., \& Tao, F. (2018). Impacts of climate change and climate extremes on major crops productivity in China at a global warming of 1.5 and 2.0 C. Earth System Dynamics, 9(2), 543562. https://doi.org/10.5194/esd-9-543-2018

Cline, W. R. (2007). Global warming and agriculture: Impact estimates by country. Washington, D. C: Peterson Institute for International Economics. 
Coirolo, C., Commins, S., Haque, I., \& Pierce, G. (2013). Climate change and social protection in Bangladesh: Are existing programmes able to address the impacts of climate change? Development Policy Review, 31, 74-90. https://doi.org/10.1111/dpr.12040

Deryng, D., Conway, D., Ramankutty, N., Price, J., \& Warren, R. (2014). Global crop yield response to extreme heat stress under multiple climate change futures. Environmental Research Letters, 9(3), 034011. https://doi.org/10.1088/1748-9326/9/3/034011

Easterling, D. R., Kunkel, K. E., Wehner, M. F., \& Sun, L. (2016). Detection and attribution of climate extremes in the observed record. Weather and Climate Extremes, 11, 17-27. https://doi.org/10.1016/j.wace.2016.01.001

Eckstein, D., Kunzel, V., Schafer, L., \& Winges, M. (2019). Global climate risk index 2020. Retrieved September 27, 2020 from https://www.germanwatch.org/en/cri

Escarcha, J., Lassa, J., \& Zander, K. (2018). Livestock under climate change: A systematic review of impacts and adaptation. Climate, 6(3), 1-17.

https://doi.org/10.3390/cli6030054

Ferdushi, K. F., Ismail, M., \& Kamil, A. A. (2019). Perceptions, knowledge and adaptation about climate change: A study on farmers of Haorareas after a flash flood in Bangladesh. Climate, 7(7), 85. https://doi.org/10.3390/cli7070085

Food and Agriculture Organization of the United Nations. (2016). The state of food and agriculture: Climate change, agriculture and food security. Rome, Italy: FAO

\section{Harris, I. C. \& Jones, P. D. (2020). CRU TS4.03: Climatic Research Unit (CRU) Time-Series (TS) version 4.03 of high-resolution gridded data of month-by-month variation in climate (Jan. 1901- Dec. 2018). Centre for Environmental Data Analysis, 25. https://doi.org/10.5285/10d3e3640f004c578403419aac167d82}

Hiwasaki, L., Luna, E., Syamsidik, \& Shaw, R. (2014). Process for integrating local and indigenous knowledge with science for hydro-meteorological disaster risk reduction and climate change adaptation in coastal and small island communities. International journal of disaster risk reduction, 10, 1527. https://doi.org/10.1016/j.ijdrr.2014.07.007

Hossain, M. S., Nayeem, A., \& Majumder, A. K. (2017). Impact of flash flood on agriculture land in Tanguar Haor Basin. International Journal of Research in Environmental Science, 3(4), 42-

45. https://doi.org/10.20431/2454-9444.0304007 
Huq, S. (2017, May 3). Are the Haor floods caused by climate change? The Daily Star. Retrieved September 29, 2020 from https://www.thedailystar.net/opinion/politics-climate-change/are-the-Haorfloods-caused-climate-change-1399543

International Fund for Agricultural Development. (2010). Rural poverty report 2011: New realities, new challenges: New opportunities for tomorrow's generation. Rome, Italy: IFAD

Intergovernmental Panel on Climate Change. (2014). Summary for policymakers. In C. B. Field, V. R. Barros, D. J. Dokken, K. J. Mach, M. D. Mastrandrea, T. E. Bilir, ... L. L. White (Eds.), Climate change 2014: Impacts, adaptation, and vulnerability. Part A:

Global and sectoral aspects. Contribution of Working Group II to the Fifth Assessment Report of the Intergovernmental Panel on Climate Change. New York, NY: Cambridge University Press.

Intergovernmental Panel on Climate Change. (2018). Summary for policymakers. In V. M. Delmotte, P. Zhai, H. O. Pörtner, D. Roberts, J. Skea, P. R. Shukla, ... T. Waterfeld (Eds.), Global warming of $1.5^{\circ} \mathrm{C}$. An IPCC special report on the impacts of global warming of $1.5^{\circ} \mathrm{C}$ above pre-industrial levels and related global greenhouse gas emission pathways, in the context of strengthening the global response to the threat of climate change, sustainable development, and efforts to eradicate poverty. Retrieved January 02, 2019, from https://www.ipcc.ch/2018/10/08/summary-for-policymakers-ofipcc-specialreport-on-global-warming-of-1-5c-approved-by-governments/

Kamal, A. M., Shamsudduha, M., Ahmed, B., Hassan, S. K., Islam, M. S., Kelman, I., \& Fordham, M. (2018). Resilience to flash floods in wetland communities of northeastern Bangladesh. International journal of disaster risk reduction, 31, 478-488. https://doi.org/10.1016/j.ijdrr.2018.06.011

Kamruzzaman, M., \& Shaw, R. (2018). Flood and sustainable agriculture in the Haor basin of Bangladesh: A review paper. Universal Journal of Agricultural Research, 6(1), 40-49. https://doi.org/10.13189/ujar.2018.060106

Knutson, T., Kossin, J., Mears, C., Perlwitz, J., \& Wehner, M. (2017). Detection and attribution of climate change. In D. J. Wuebbles, D.W. Fahey, K. A. Hibbard, D. J. Dokken, B. C. Stewart, \& T. K. Maycock (Eds.), Climate science special report: Fourth National Climate Assessment. (pp. 114-132). https://doi.org/10.7930/J01834ND

Maddison, D. (2007). The perception of and adaptation to climate change in Africa. The World Bank Policy Research Working Paper 4308. Retrieved September 15, 2020 from http://documents1.worldbank.org/curated/en/479641468193774164/pdf/wps4308.pdf

Mader, T. L., \& Gaughan, J. B. (2011). Effects of climate variability on domestic livestock. In A. Dinar., R. Mendelsohn (Eds.), Handbook on climate change and agriculture. (pp. 32-48). Cheltenham, UK: Edward 
Elgar.

Mahtab, M. H., Ohara, M., \& Rasmy, M. (2018). The Impact of Rainfall Variations On Flash Flooding In Haor Areas In Bangladesh. Water Conservation \& Management (WCM), 2(2), 6-

10. https://doi.org/10.26480/wcm.02.2018.06.10

Mertz, O., Mbow, C., Reenberg, A., \& Diouf, A. (2009). Farmers' perceptions of climate change and agricultural adaptation strategies in rural Sahel. Environmental management, 43(5), 804-

816. https://doi.org/10.1007/s00267-008-9197-0

Monwar, M. M., Mustafa, M. G., Khan, N. A., Hossain, M. S., Hossain, M. M., Majumder, M. K., ... \& Alam, M. S. (2018). Indigenous adaptation practices for the development of climate resilient ecosystems in the Hail Haor, Bangladesh. Global Social Welfare, 5(2), 125-136. https://doi.org/10.1007/s40609-014-0014-9

Nelson, D. R., Adger, W. N., \& Brown, K. (2007). Adaptation to environmental change: contributions of a resilience framework. Annual Review of Environment and Resources, 32, 395-

419. https://doi.org/10.1146/annurev.energy.32.051807.090348

Rahman, M., \& Alam, K. (2016). Forest dependent indigenous communities' perception and adaptation to climate change through local knowledge in the protected area-A Bangladesh case study. Climate, 4(1), 12. https://doi.org/10.3390/cli4010012

Rotter, B., \& Van de Geijn, S. C. (1999). Climate change effects on plant growth, crop yield and livestock. Climatic Change, 43(4), 651-681. https://doi.org/10.1023/A:1005541132734

The Global Economy. (2020). Bangladesh: Literacy rate. Retrieved October 13, 2020 from https://www.theglobaleconomy.com/Bangladesh/literacy_rate/

The Guardian (2019, May 17). Why the Guardian is changing the language it uses about the environment. The Guardian. Retrieved September 29, 2020

from https://www.theguardian.com/environment/2019/may/17/why-the-guardian-is-changing-thelanguage-it-uses-about-the-environment

Thornton, P. K., van de Steeg, J., Notenbaert, A., \& Herrero, M. (2009). The impacts of climate change on livestock and livestock systems in developing countries: A review of what we know and what we need to know. Agricultural systems, 101(3), 113-127. https://doi.org/10.1016/j.agsy.2009.05.002

Wreford, A., Moran, D., \& Adger, N. (2010). Climate change and agriculture: Impacts, adaptation and mitigation. https://doi.org/10.1787/9789264086876-en

\section{Figures}



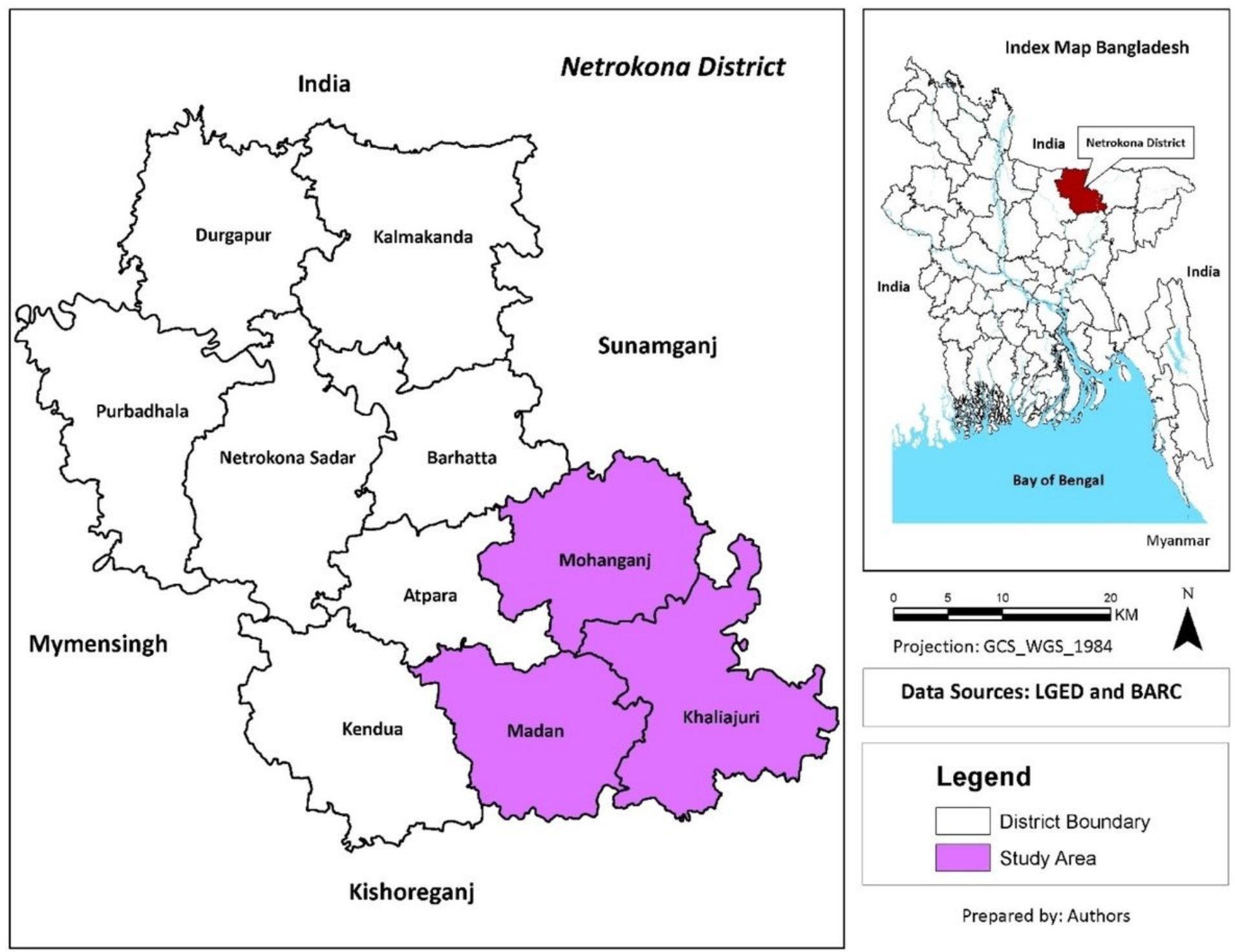

Prepared by: Authors

Figure 1

Map of Study Area. Note: The designations employed and the presentation of the material on this map do not imply the expression of any opinion whatsoever on the part of Research Square concerning the legal status of any country, territory, city or area o bbnhjr of its authorities, or concerning the delimitation of its frontiers or boundaries. This map has been provided by the authors. 


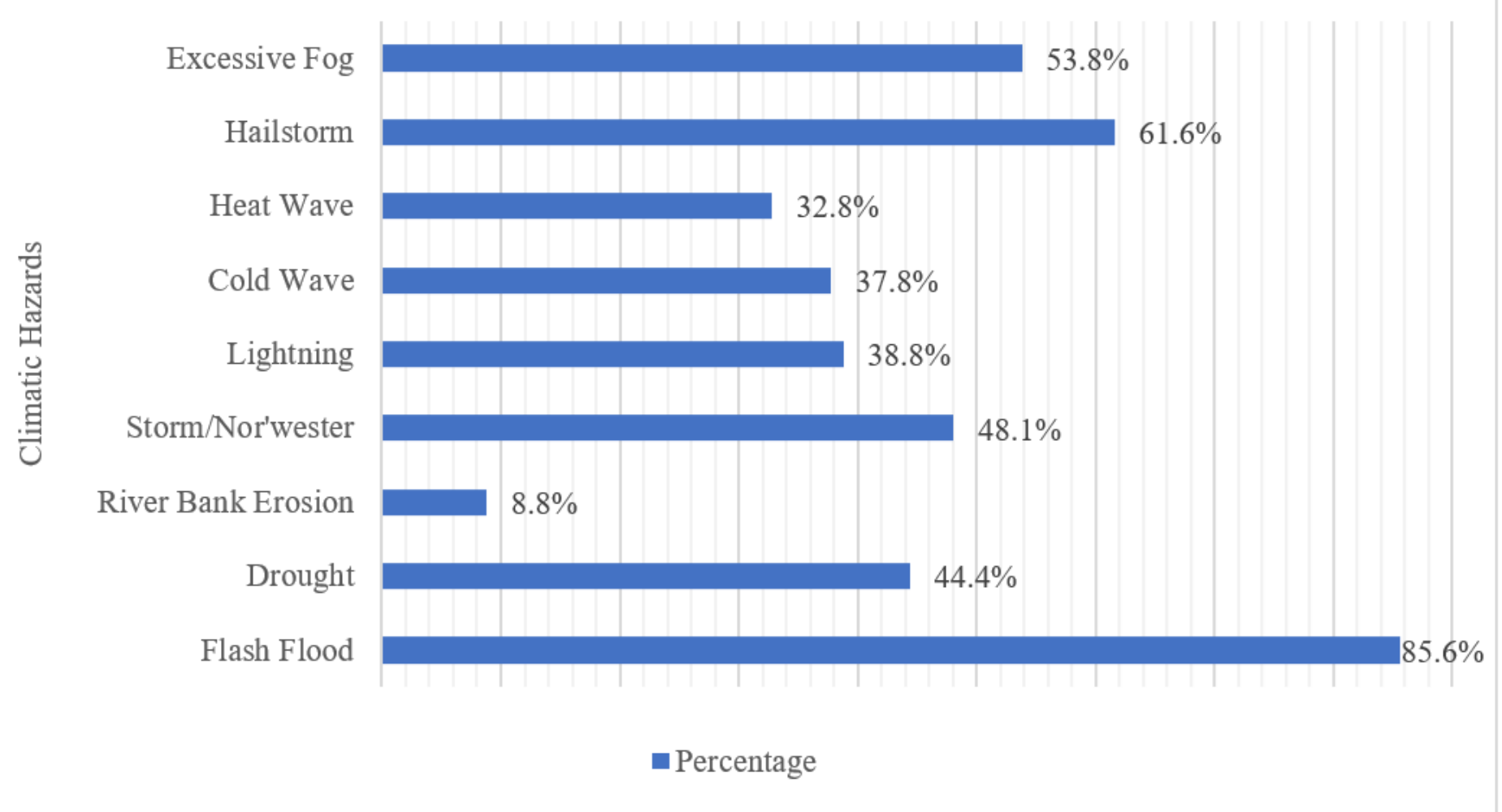

Figure 2

Major Climatic Hazards in the Study Area (Respondents' View)

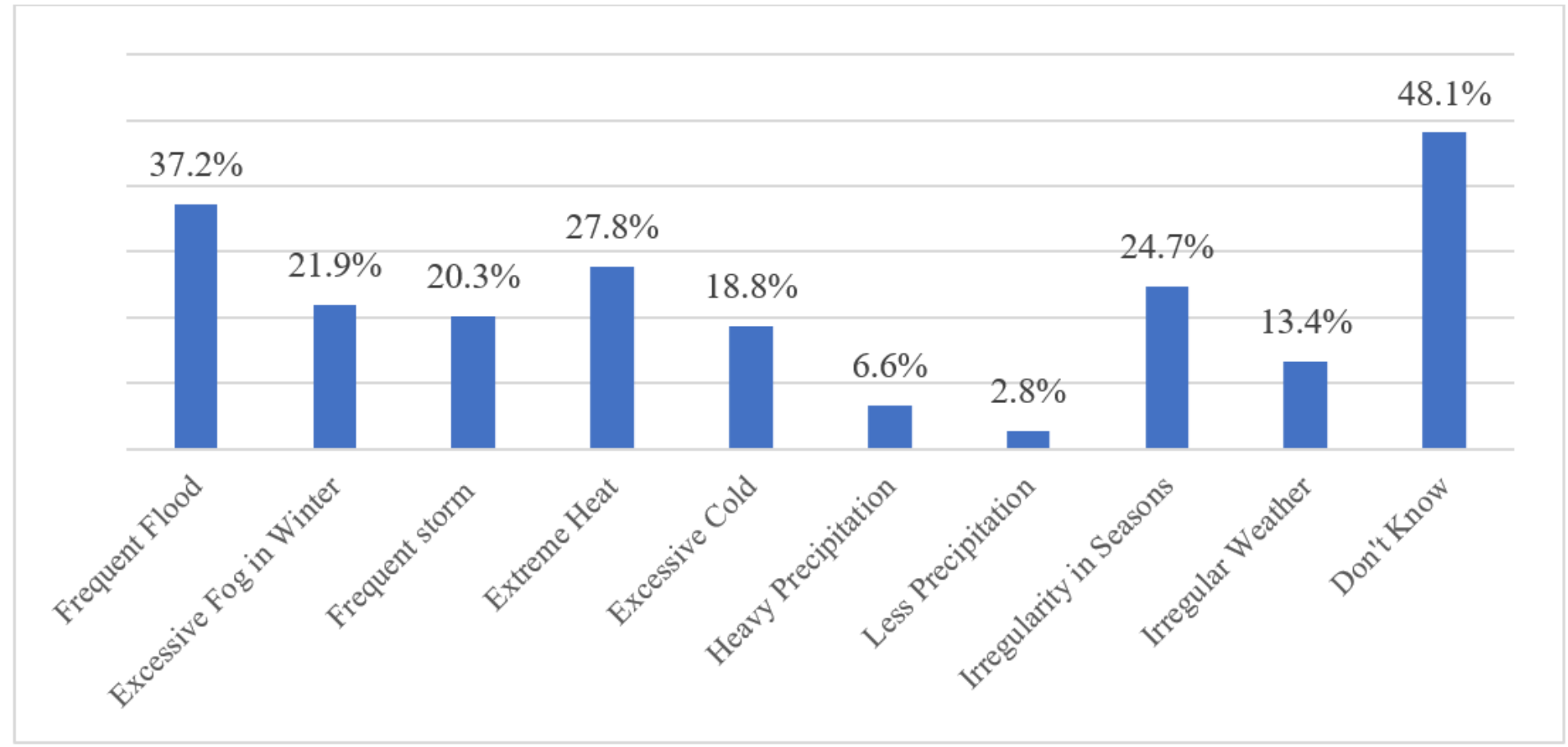

Figure 3

Respondents' Understanding about Climate Change 


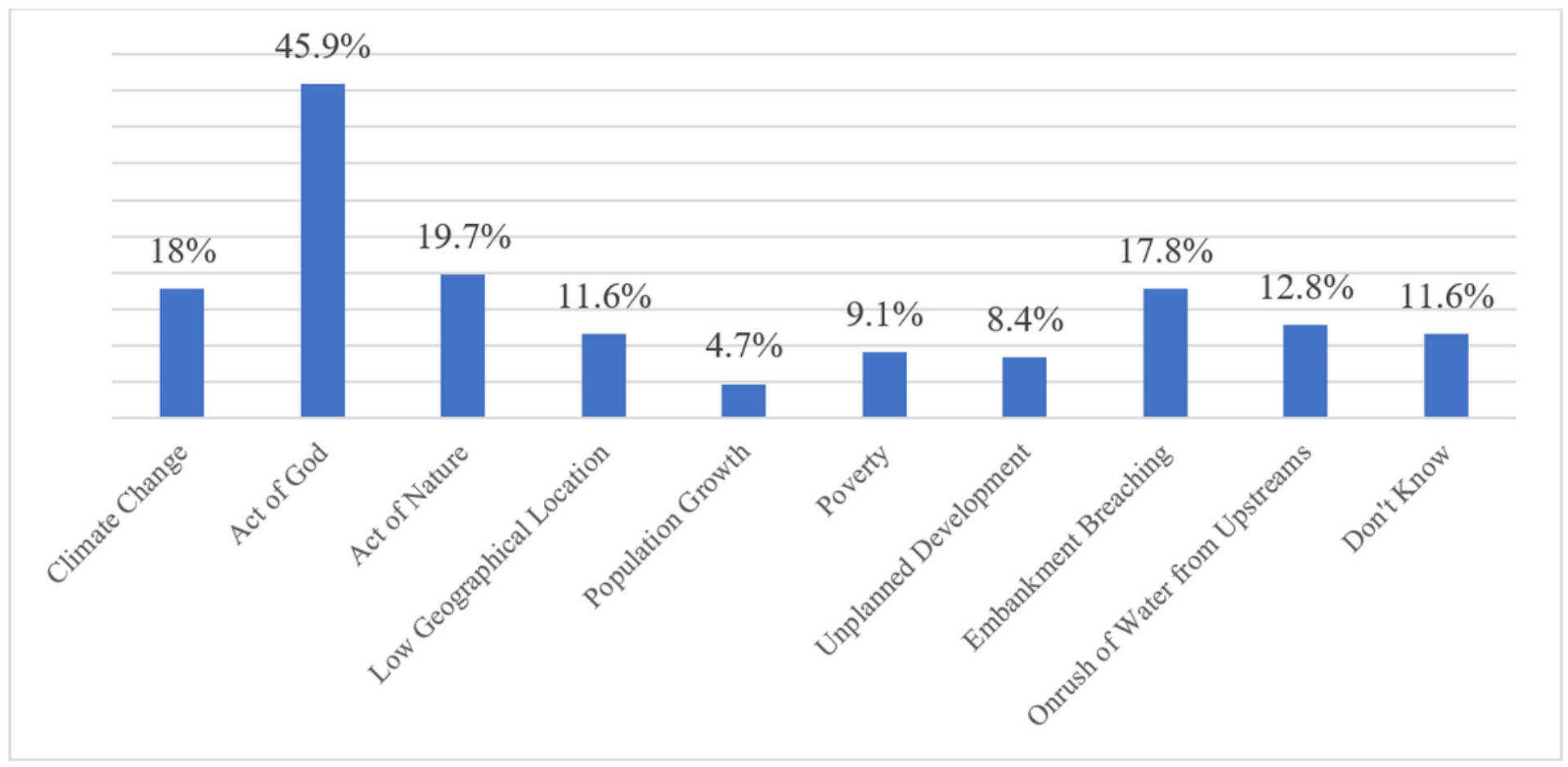

\section{Figure 4}

Respondents' Perception on the Reasons of Hazards/Disasters

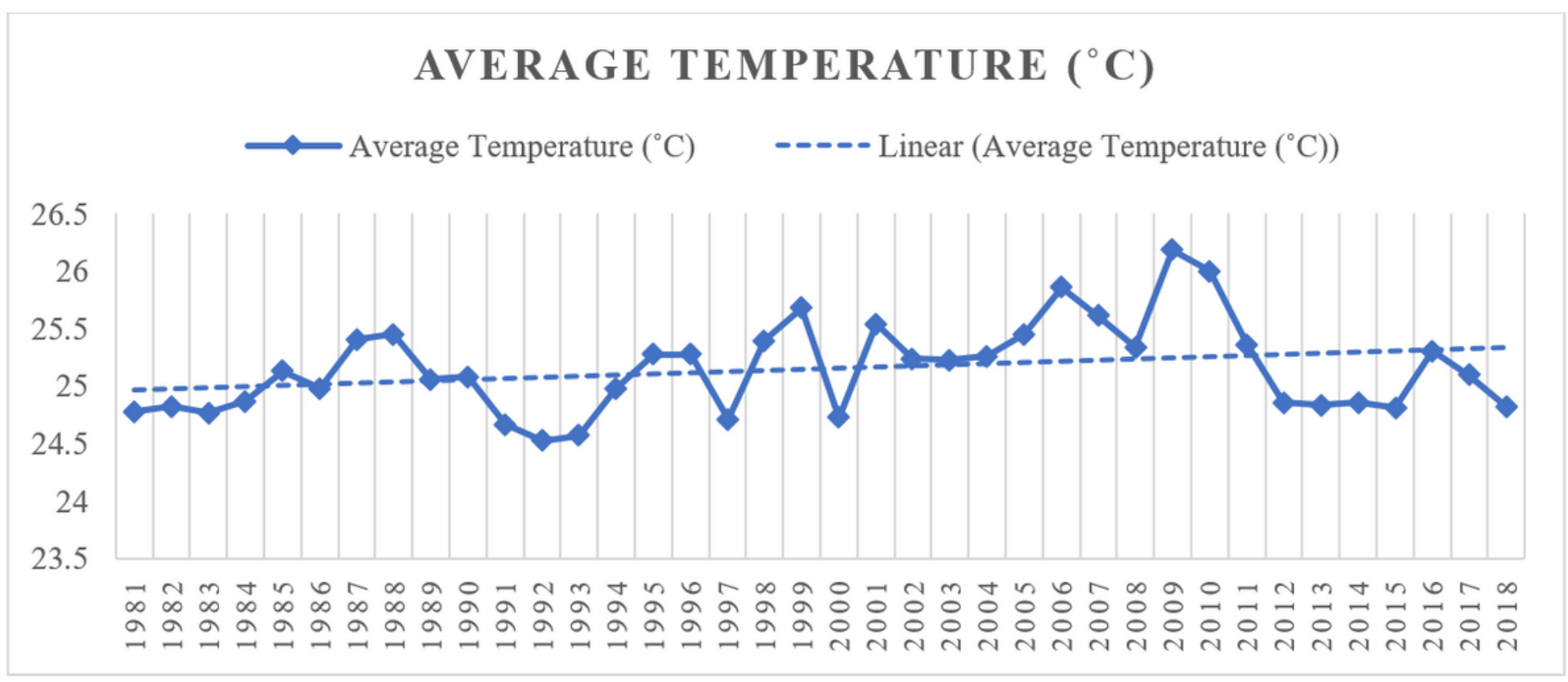

Figure 5

Average Annual Temperature $\left({ }^{\circ} \mathrm{C}\right)$ of Netrokona District with the Trendline (1981-2018) 


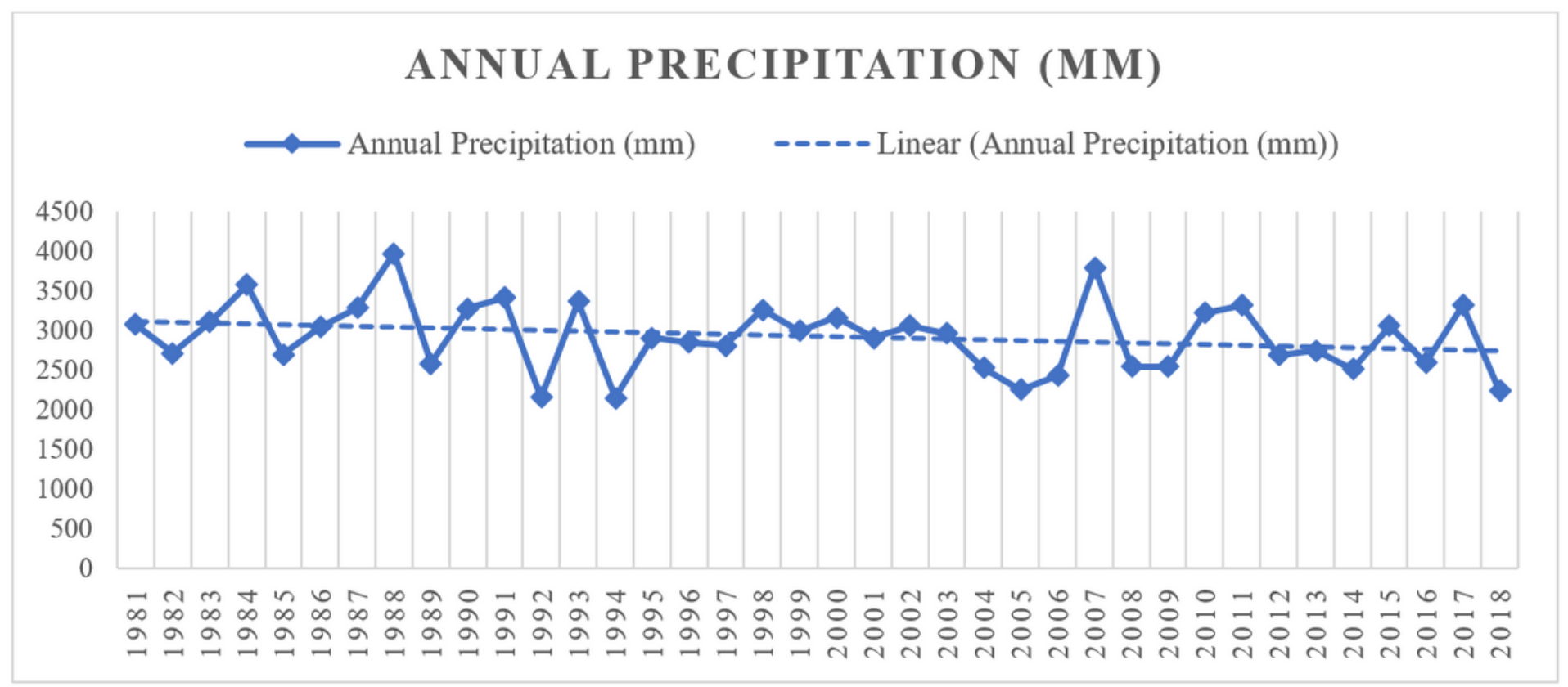

\section{Figure 6}

Annual Precipitation (mm) of Netrokona District with the Trendline (1981-2018)

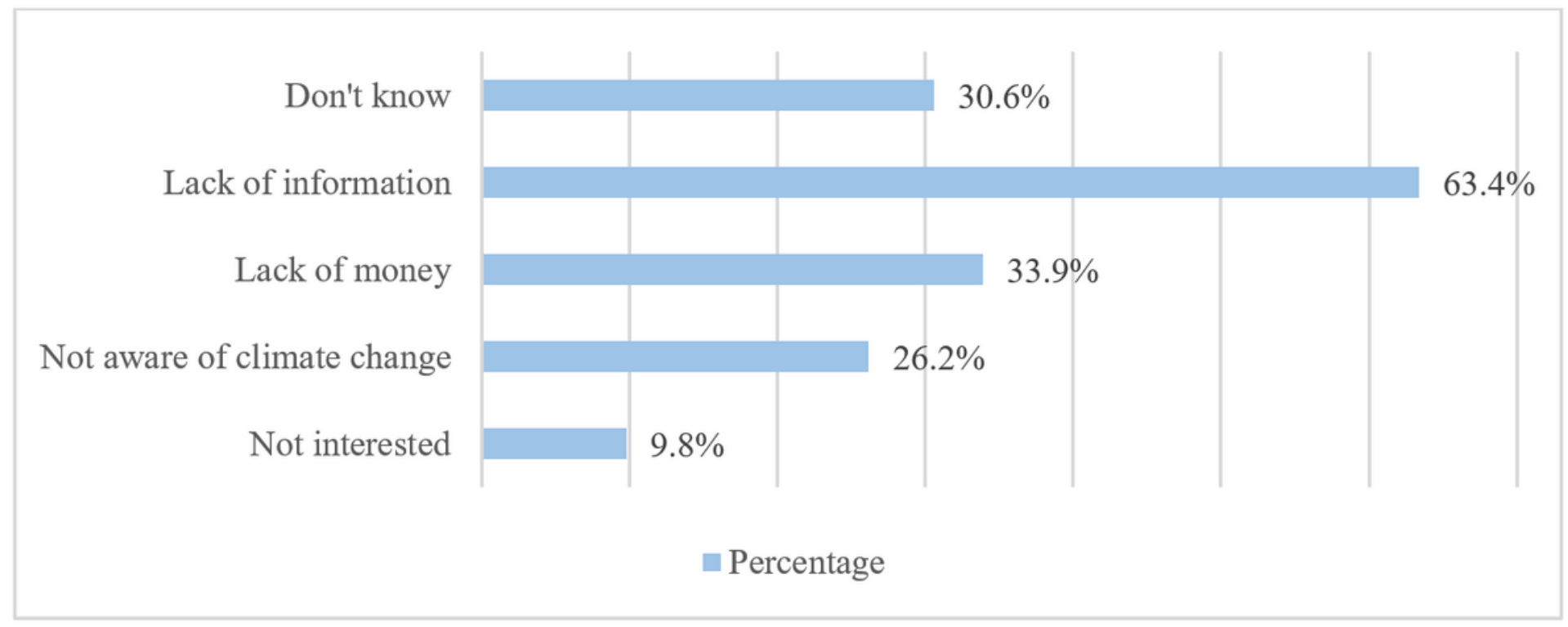

\section{Figure 7}

Reasons of not Taking Adaptation Measures 